\title{
The Occurrence of Cereal Cultivation in China
}

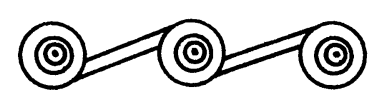

TRACEY L-D LU

NeARly EIghty YeARS HAVE ElAPSED since Swedish scholar J. G. Andersson discovered a piece of rice husk on a Yangshao potsherd found in the middle Yellow River Valley in 1927 (Andersson 1929). Today, many scholars agree that China $^{1}$ is one of the centers for an indigenous origin of agriculture, with broomcorn and foxtail millets and rice being the major domesticated crops (e.g., Crawford 2005; Diamond and Bellwood 2003; Higham 1995; Smith 1995) and dog and pig as the primary animal domesticates (Yuan 2001). It is not clear whether chicken and water buffalo were also indigenously domesticated in China (Liu 2004; Yuan 2001).

The origin of agriculture in China by no later than 9000 years ago is an important issue in prehistoric archaeology. Agriculture is the foundation of Chinese civilization. Further, the expansion of agriculture in Asia might have related to the origin and dispersal of the Austronesian and Austroasiatic speakers (e.g., Bellwood 2005; Diamond and Bellwood 2003; Glover and Higham 1995; Tsang 2005). Thus the issue is essential for our understanding of Asian and Pacific prehistory and the origins of agriculture in the world.

Many scholars have discussed various aspects regarding the origin of agriculture in China, particularly after the 1960s (e.g., Bellwood 1996, 2005; Bellwood and Renfrew 2003; Chen 1991; Chinese Academy of Agronomy 1986; Crawford 1992, 2005; Crawford and Shen 1998; Flannery 1973; Higham 1995; Higham and Lu 1998; Ho 1969; Li and Lu 1981; Lu 1998, 1999, 2001, 2002; MacNeish et al. 1998; Smith 1995; Sun et al. 2001, 2002; Tao 1994; Wang et al. 1998; Yan 1992). This paper will focus on the occurrence of cereal cultivation in North China and the Yangzi (Yangtze) River Valley, which resulted in the origin of agriculture in both areas.

According to Price and Gebauer (1995:6), "Cultivation ... is a cultural phenomenon that involves intentionally preparing fields, sowing, harvesting, and storing seeds or other plant parts," and is an essential part of agriculture. They further argue that sedentism, population, resource abundance, and social changes were important factors in the transition from foraging to farming in many parts of the world. Based on current archaeological and experimental findings, this paper will examine the aforementioned important factors, as well as the similarities and

Tracey L-D Lu is an associate professor in the Department of Anthropology at the Chinese University of Hong Kong, Shatin, N. T., Hong Kong. 
differences in terms of the occurrence of cereal cultivation in China and in other core areas of agricultural origin elsewhere. It will be argued that the transition from foraging to farming in China might have differed from those in the Middle East and Mesoamerica, particularly in terms of sedentism, social structure, population density, and the occurrence of pottery.

To date, studies on this issue have been focusing on when and where cultivation began in China, and what has been domesticated. Various approaches have been used to reconstruct the palaeoenvironment and palaeoclimate, to investigate the wild progenitors of domesticated plants and animals and the domestication processes, and to search for more archaeological data for the issues of why, by whom, and how cereal cultivation occurred.

\section{THE RECONSTRUCTED PALAEOCLIMATES AND PALAEOENVIRONMENTS}

It has been argued that the origin of agriculture might have related to certain climatic and environmental changes from the terminal Pleistocene to the early Holocene (i.e., Watson 1995). Globally, this period is characterized by the termination of the Last Glacial Maximum (LGM) toward the terminal Pleistocene and the warming of the early Holocene. Did the palaeoclimate in China also conform to this climatic pattern? Various methods-including pollen profiles, sea and freshwater level changes, mineralogical studies, faunal analysis, isotopic analysis of ice cores, and soil analysis-have been used to tackle this issue (e.g., Jiang and Piperno 1999; Lu et al. 2000; Ren and Beug 2002; Yi et al. 2003). Generally speaking, the Last Glacial Maximum had a significant impact on the landmass called China today, causing lower temperatures and reduced precipitation and water supply. Deciduous trees retreated from both North China and some areas of the Yangzi River Valley to southern areas, and grasses dominated many landscapes (Lu et al. 2000; Ren and Beug 2002; Yi et al. 2003). During the LGM, the average annual temperature was probably $6-9^{\circ} \mathrm{C}$ lower than today in North China and about $4-5{ }^{\circ} \mathrm{C}$ lower in the Yangzi River Valley (Chen et al. 2002; Lu 1999).

Recently, it is further observed that the climatic fluctuations were variable in their effects due to different topographic conditions and the circulation of the monsoons in winter and summer in China (He et al. 2004). Some scholars argue that the glacial impact was greater in regions of higher latitudes (i.e., latitudes of $25^{\circ} \mathrm{N}$ and above) than that of lower latitudes and that the western part of China was more sensitive to climatic changes than the eastern region (ibid.). Whether such climatic and-consequently-resource variations had any impact on the origins of farming in the eastern part of China is a question for further study.

From 13,000 to 10,000 B.P., the palaeoclimate became warmer and moister, but with fluctuations. Pollen profiles indicate a sharp decrease of temperatures and precipitations in both North China and the Yangzi River Valley between approximately 12,000 and 10,300 B.P., represented by the sudden decrease of trees and the increase of herbs, including many species of the grass family (Liu and Chang 1996; Yi et al. 2003), causing a decreased supply of edible fruit and nuts and an increased supply of grass seeds ( $\mathrm{Li} 1998$; Lu 1999). This event is comparable to the Younger Dryas in Europe, although the time span seems slightly different (Yi et al. 2003). 
After 10,000 B.P., both the temperature and precipitation continued to rise. China experienced the Holocene optimum from approximately 9000 to 3000 years ago, although with fluctuations (He et al. 2004). Remains of many species of plants and wild animals have been widely found, particularly herbivores and rodents (Zhou 1984), associated with many farming societies from North China to the Yangzi River Valley during this period (Table 2).

The cold climate at the terminal Pleistocene might have driven local peoples in these areas to obtain more storable food in the winter, and the incipient cultivation might have been one of their subsistence strategies. It was probably the warm and humid climate after 10,000 years ago that enabled the intensification of cereal cultivation in China. However, at present there is a lack of detailed studies on the seasonality, availability, and reliability of the faunal and floral resources in North China and the Yangzi River Valley between 13,000 and 9000 years ago, so the climatic impact on the origin of farming in China remains unclear.

\section{THE INCIPIENT CULTIVATORS OF CHINA}

From the 1970s onward, many archaeological assemblages with domesticated millet and/or rice have been found in China (Fig. 1; Tables 1 and 2). Based on these data, the prehistoric societies dated between 9000 and 7000 B.P. were sedentary farmers, although large quantities of wild animal bones and wild fruits are also found, indicating that hunting and gathering were still part of their subsistence strategies. The quantity of cereal remains found in these sites suggests that they

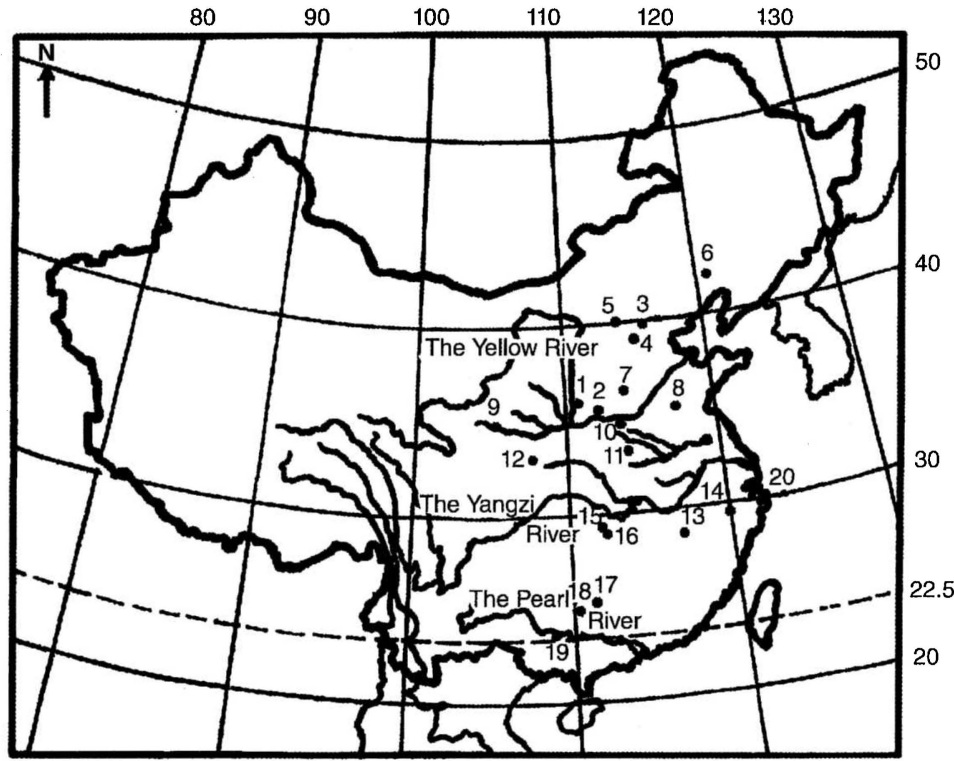

Fig. 1. Archaeological sites mentioned in the text: 1: Shizitan; 2: Xiachuan; 3: Donghulin; 4: Nanzhuangtou; 5: Hutouliang; 6: Xinglonggou; 7: Cishan; 8: Beixin; 9: Dadiwan; 10: Peiligang; 11: Jiahu; 12: Lijiacun; 13: Xianrendong/Diaotonghuan; 14: Shangshan; 15: Pengtoushan; 16: Bashidang; 17: Yuchanyan; 18: Zengpiyan; 19: Dingsishan; 20: Hemudu. 
Table i. Archaeological Assemblages Dated between i 3,000 and 9000 B.P. in China

\begin{tabular}{|c|c|c|c|c|}
\hline SITE & $\begin{array}{l}\text { LOCATION AND SITE } \\
\text { STRUCTURE }\end{array}$ & ARCHAEOLOGICAL DATA & ${ }^{14}$ C (CAL. B.P.) ${ }^{*}$ & SOURCES \\
\hline $\begin{array}{l}\text { Shizitan, Ji County, } \\
\text { Shanxi Province }\end{array}$ & $\begin{array}{c}110^{\circ} 31^{\prime} \mathrm{E}, 36^{\circ} 5^{\prime} 40^{\prime \prime} \mathrm{N} \\
\text { Open site at river } \\
\text { terrace composed } \\
\text { of } 25 \text { finding } \\
\text { places; sizes of each } \\
\text { place not reported. }\end{array}$ & $\begin{array}{l}\text { More than ten hearths, remains of manufacturing } \\
\text { stone tools, over } 3000 \text { artifacts including micro- } \\
\text { blades, grinding slabs, rolling stones, and } \\
\text { abraders; large quantities of animal bones and } \\
\text { shells. Species not reported. }\end{array}$ & $\begin{array}{l}\text { Estimated between } \\
20,000 \text { and } 10,000 \\
\text { years ago }\left({ }^{14} \mathrm{C}\right. \\
\text { dates not yet } \\
\text { reported }) .\end{array}$ & $\begin{array}{l}\text { National Bureau } \\
\text { of Antiquity } \\
\text { Management } \\
2004 \text {. }\end{array}$ \\
\hline $\begin{array}{l}\text { Donghulin, Beijing } \\
\text { City }\end{array}$ & $\begin{array}{l}116^{\circ} 18^{\prime} \mathrm{E}, 39^{\circ} 58^{\prime} \mathrm{N} \\
\text { Open site at river } \\
\text { terrace; exact size } \\
\text { of the site not } \\
\text { reported. }\end{array}$ & $\begin{array}{l}\text { Grinding slabs and stones, flaked stone and shell } \\
\text { tools, coarse pottery tempered with quartz and } \\
\text { made by slab building, the majority being plain, } \\
\text { some decorated with appliqués; partially ground } \\
\text { axes, animal bones dominated by deer and fresh } \\
\text { water shells; hearths and one tomb containing } \\
\text { three skeletons. }\end{array}$ & $\begin{array}{l}\text { Ten dates between } \\
10,350 \text { and } 9540 \\
\text { B.P., only details } \\
\text { of two dates are } \\
\text { reported: } \\
\text { Cal. } 10,161- \\
8489 \text {; } \\
\text { Cal. } 9581-9331 \text {. }\end{array}$ & $\begin{array}{l}\text { Zhao et al. 2003; } \\
\text { Donghulin } \\
\text { Archaeological } \\
\text { Team 2003. }\end{array}$ \\
\hline $\begin{array}{l}\text { Nanzhuangtou, } \\
\text { Xushui County, } \\
\text { Hebei Province }\end{array}$ & $\begin{array}{l}115^{\circ} 36^{\prime} \mathrm{E}, 39^{\circ} \mathrm{N} \\
\text { Open site in North } \\
\text { China plain. }\end{array}$ & $\begin{array}{l}\text { Ditches and hearths; grinding slabs and stones, } \\
\text { pottery, lithic flakes, and bone drills; remains of } \\
\text { four species of deer, wolf, pig (not sure whether } \\
\text { it was domesticated), birds, tortoise, freshwater } \\
\text { shellfish, etc. }\end{array}$ & $\begin{array}{c}\text { Cal. } 12,593-12,236, \\
12,215-11,634, \\
10,991-10,615, \\
10,971-10,389, \\
10,921-10,473, \\
10,899-10,386, \\
10,800-10,300, \\
10,782-10,298, \\
10,361-10,044, \\
9540-9440, \\
9185-8563\end{array}$ & Guo and Li 2000. \\
\hline $\begin{array}{l}\text { Hutouliang, Yangyuan } \\
\text { County, Hebei } \\
\text { Province }\end{array}$ & $\begin{array}{l}114^{\circ} 9^{\prime} \mathrm{E}, 40^{\circ} 1^{\prime} \mathrm{N} \\
\text { Nine open sites at } \\
\text { river terrace. }\end{array}$ & $\begin{array}{l}\text { Flaked tools, debitage, microblades and microcores; } \\
\text { pottery; charcoal, hearths; animal bones of fox, } \\
\text { ostrich, various species of mice, wolf, wild horse, } \\
\text { deer, ox, wild boar, and gazelle. }\end{array}$ & $\begin{array}{l}11,870 \pm 1720 \\
\text { (TL dating, no } \\
\text { calibrating) }\end{array}$ & Guo and Li 2000. \\
\hline
\end{tabular}


Xianrendong/

Diaotonghuan,

Wannian County,

Jiangxi Province

Shangshan, Pujiang

County, Zhejiang

Province

Yuchanyan, Dao County, Hunan

Province

Zengpiyan, Guilin City, Guangxi

Municipality $117^{\circ} 13^{\prime} \mathrm{E}, 28^{\circ} 44^{\prime} \mathrm{N}$ Cave in limestone area.

$120^{\circ} \mathrm{E}, 29^{\circ} 29^{\prime} \mathrm{N}$ Open site in the Yangzi Valley.

$111^{\circ} 30^{\prime} \mathrm{E}, 25^{\circ} 30^{\prime} \mathrm{N}$ Cave in limestone area.

$110^{\circ} 16^{\prime} \mathrm{E}, 25^{\circ} 12^{\prime} \mathrm{N}$ Cave in limestone area.
Pebble choppers, hammers, and one pierced stone disk; small flaked "scrapers" and other

implements made of chert and quartz, bone arrowheads and harpoons, perforated shell and antler implements; hearths, shells, animal bones (species not yet reported). Coarse pottery with stripe impression or cord mark, or plain,

tempered mainly with quartz and built by slab building and coiling; only a round-bottomed cauldron can be reconstructed. Rice phytolith found from the early to the late deposits.

Pebble spheres, pierced disks, and grinding slabs and rollers, small quantity of ground stone adzes and axes. Coarse pottery built by slab building and tempered with rice husks, mainly plain, occasionally with motifs of cord mark, stamping, and incision; major vessels are flat-bottomed basins, also some caldrons and pots. Pile holes and pits, etc.

Hearths. Pebble choppers and chopping tools, bone and antler drills, very crumbly and coarse pottery probably made by slab building and tempered with quartz and charcoal, with cord mark on the interior and exterior surfaces; over 40 species of plant (including rice husks and phytolith) and 45 species of animal and shell remains (no details)

Burials, pebble tools, bone and antler drills, and points and shell knives, very crumbly and coarse pottery made by hand-pitching and slab building and tempered with calcite and quartz, with cord mark on the interior and external surfaces; 108 species of plant (mainly roots) and animal and shell remains. No traces of rice found.
Estimated between

15,000 and 12,000

by the excavators.

Four dates:

11,217-10,478,

9957-9586

9941-9347,

9177-9650

$15,131-13,915$

$18,535-17,055$

18,150-16,697

$12,000-7000$

The Institute of Archaeology, CASS et al. 2003.
MacNeish and Libby 1995;

Zhang 2000

Zhao 1998.

Jiang et al. 2003.

Yuan 2000

(Continued) 
TABLE I (Continued)

\begin{tabular}{|c|c|c|c|c|}
\hline SITE & $\begin{array}{l}\text { LOCATION AND SITE } \\
\text { STRUCTURE }\end{array}$ & ARCHAEOLOGICAL DATA & ${ }^{{ }^{I 4} \mathrm{C}}$ (CAL. B.P.)* & SOURCES \\
\hline $\begin{array}{l}\text { Dingsishan, Yongnin } \\
\text { County, Guangxi }\end{array}$ & $\begin{array}{l}108^{\circ} 30^{\prime} \mathrm{E}, 22^{\circ} 45^{\prime} \mathrm{N} \\
\text { Open site at river } \\
\text { terrace. }\end{array}$ & $\begin{array}{l}\text { Tecktile, pebble, bone drills, and shell knives, } \\
\text { coarse pottery tempered with calcite and } \\
\text { decorated with appliqués, over } 20 \text { species of } \\
\text { animal and plant remains. Rice phytolith found } \\
\text { in period dated to } 6000-6500 \text { B.P. }\end{array}$ & $10,000-6000$ & Fu 2003 \\
\hline
\end{tabular}

*Used CALIB rev. 4.4.2 (Stuiver and Reimer 2004). 
were not at the initial stage of cereal cultivation. So who were the incipient cultivators $^{2}$ in China?

Some archaeological assemblages dated before 10,000 years ago have been found in North China and the Yangzi Basin in recent years. Although details of these archaeological assemblages are not published, the site structures and toolkits of these assemblages may give us some clues about the early cultivators (Table 1).

"North China" here refers to the vast area from the Yellow River Valley to Inner Mongolia, or approximately between latitudes $35^{\circ}$ to $45^{\circ} \mathrm{N}$ (Fig. 1). The Shizitan, Nanzhuangtou, and Donghulin assemblages dated between 10,000 and 9000 years ago have been found here (Table 1). They are open sites located on river terrace (Shizitan) or open plain (Nanzhuangtou and Donghulin). Although macro- or microremains of cultivated plants have not been discovered so far, grinding slabs and hand stones have been found in all of them, associated with flaked blades and other heavy-duty tools.

The earliest grinding slabs and hand stones in China were found in Xiachuan, Shanxi Province, in the 1970s, associated with chert-flaked blades and other heavy-duty stone tools and dated to approximately 23,000 to 13,000 years ago (Fig. 1; Wang et al. 1978). A preliminary use-wear analysis of the Xiachuan flakes indicates the practice of reaping grass panicles $(\mathrm{Lu} 2001)$. According to research in the Middle East, the consumption of grass seeds and harvesting of wild grasses is considered as a prelude to the occurrence of cultivation (e.g., Anderson 1992), although it may not necessarily lead to the latter. In addition, grinding slabs and cutting tools are found both in Xiachuan and in the succeeding farming societies in North China, suggesting a possible cultural continuity from the Upper Paleolithic to the early Neolithic ( $\mathrm{Lu} 1999)$. Millet cultivation might have developed from the wild grass collectors in this area, with the three newly found archaeological assemblages being the link between Xiachuan and the Neolithic farmers dated after 9000 years ago (Tables 1 and 2). Of course, more work is required to investigate the subsistence strategies of the three assemblages.

Archaeological assemblages dated to 10,000 years or earlier in the Yangzi Basin - the Xianrendong/Diaotonghuan and Yuchanyan-are all found in caves or rock shelters with remains of rice (Table 1). The toolkits of these assemblages consist of pebble tools, bone and antler implements, and some small flakes. Grinding slabs are absent. As no use-wear analysis has been carried out for the flakes found in the Yangzi Basin, it is unclear whether they served as cutting tools.

Rice phytoliths have been found in the Xianrendong/Diaotonghuan assemblages (MacNeish et al. 1998:26; Zhao 1998). Based on phytolith analysis, Zhao has argued for the occurrence of rice collection at around 12,000-11,000 years ago at Diaotonghuan (Zhao 1998:893; Zhao et al. 1998). Both wild and domesticated rice were found in deposits dated between 10,000 and 8000 years ago in Diaotonghuan, and the two species "have equal weights in the assemblage" (Zhao 1998:893). This result seems to suggest that by 10,000 to 8000 years ago rice had been domesticated at Diaotonghuan, while wild rice was still collected.

Rice husks and phytoliths are also found in Yuchanyan, Hunan Province, and have been identified as a species at the early stage of being cultivated (Yuan $2000: 36)$. The archaeological contexts of these rice remains are dated to between 
Table 2. Representative Farming Societies Dated between 9000 and 7000 b.P. in China

\begin{tabular}{|c|c|c|c|c|}
\hline SITE & $\begin{array}{l}\text { LOCATION AND SITE } \\
\text { STRUCTURE }\end{array}$ & ARCHAEOLOGICAL DATA & ${ }^{\mathrm{I} 4} \mathrm{C}$ (CAL. B.P.) & SOURCES \\
\hline $\begin{array}{l}\text { Xinglonggou, Aohan } \\
\text { Region, Inner } \\
\text { Mongolia }\end{array}$ & $\begin{array}{l}120^{\circ} 45^{\prime} \mathrm{E}, 42^{\circ} 25^{\prime} \mathrm{N} \\
\text { Open site at river } \\
\text { terrace. }\end{array}$ & $\begin{array}{l}\text { Protective ditches, remains of over } 40 \\
\text { houses, pits, tens of in-house burials; } \\
\text { grinding slabs, lithic spheres, ground } \\
\text { stone spades, axes and adzes, } \\
\text { microblades, pottery, jade items; } \\
\text { animal remains (particularly wild } \\
\text { boar) and foxtail millet. }\end{array}$ & $\begin{array}{l}\text { Estimated to be between } \\
8000 \text { and } 7500 \text { B.P. by the } \\
\text { excavators. }\end{array}$ & $\begin{array}{l}\text { National Bureau of Antiquity } \\
\text { Management 2004; Liu et al. } \\
2004 .\end{array}$ \\
\hline $\begin{array}{l}\text { Cishan, Wuan County, } \\
\text { Hebei Province }\end{array}$ & $\begin{array}{l}114^{\circ} 5^{\prime} \mathrm{E}, 36^{\circ} 32^{\prime} \mathrm{N} \\
\text { Open site at river } \\
\text { terrace, near the } \\
\text { Taihang Mountain. }\end{array}$ & $\begin{array}{l}\text { Storage pits and subterraneous houses; } \\
\text { flaked choppers and spheres, } \\
\text { grinding slabs and rollers, ground } \\
\text { spades, axes, adzes, chisels, and } \\
\text { sickles; bone arrowheads and } \\
\text { harpoons; large quantities of foxtail } \\
\text { millet, remains of pig, dog, } \\
\text { chicken, ox, and } 19 \text { species of wild } \\
\text { animals. }\end{array}$ & $\begin{array}{l}\text { Three dates: Cal. 8052-7826, } \\
\text { 7918-7691, 7722-7550. }\end{array}$ & $\begin{array}{l}\text { Institute of Archaeology, } \\
\text { CASS } 1984,1991 .\end{array}$ \\
\hline $\begin{array}{l}\text { Dadiwan, Qin'an } \\
\text { County, Gansu } \\
\text { Province }\end{array}$ & $\begin{array}{l}105^{\circ} 35^{\prime} \mathrm{E}, 34^{\circ} 58^{\prime} \mathrm{N} \\
\text { Open site at river } \\
\text { terrace. }\end{array}$ & $\begin{array}{l}\text { Subterraneous houses, burials with } \\
\text { grave goods, ceramic vessels of } \\
\text { cauldron, bowls and pots, remains } \\
\text { of broomcorn millet and } \\
\text { rapeseed (Brassica sp. Linnaeus), } \\
\text { deer, and freshwater shellfish. }\end{array}$ & $\begin{array}{l}\text { Cal. 7884-7639, 7620-7478, } \\
\text { 7523-7385, 7520-7190. }\end{array}$ & $\begin{array}{l}\text { Xia Nai 1985; Institute of } \\
\text { Archaeology, CASS } 1991 .\end{array}$ \\
\hline $\begin{array}{l}\text { Peiligang, Xinzheng } \\
\text { County, Henan } \\
\text { Province. }\end{array}$ & $\begin{array}{l}113^{\circ} 45^{\prime} \mathrm{E}, 34^{\circ} 25^{\prime} \mathrm{N} \\
\text { Open site at river } \\
\text { terrace. }\end{array}$ & $\begin{array}{l}\text { Storage pits, kilns, and } 114 \text { burials. } \\
\text { Grinding slabs and rollers, spades, } \\
\text { sickles and remains of foxtail } \\
\text { millet. }\end{array}$ & $\begin{array}{l}11,413-9958,7993-7519 \\
7898-7642 .\end{array}$ & $\begin{array}{l}\text { Institute of Archaeology, } \\
\text { CASS } 1984,1991 .\end{array}$ \\
\hline $\begin{array}{l}\text { Beixin, Teng County, } \\
\text { Shandong Province }\end{array}$ & $\begin{array}{l}117^{\circ} 16^{\prime} \mathrm{E}, 34^{\circ} 56^{\prime} \mathrm{N} \\
\text { Open site. }\end{array}$ & $\begin{array}{l}\text { Burials, pottery; some vessels were } \\
\text { painted; flaked and ground stone } \\
\text { tools. Imprinted foxtail millets on } \\
\text { pottery. }\end{array}$ & $\begin{array}{l}8008-7301,7472-6804 \\
7257-6604,7226-6548 .\end{array}$ & $\begin{array}{l}\text { Institute of Archaeology, } \\
\text { CASS 1984, } 1991 .\end{array}$ \\
\hline
\end{tabular}


Jiahu, Wuyang

County, Henan

Province

Lijiacun, Xixiang County, Shaanxi Province.

Pengtoushan and Bashidang, Li

County, Hunan

Province $113^{\circ} 30^{\prime} \mathrm{E}, 33^{\circ} 24^{\prime} \mathrm{N}$

Open site.

$107^{\circ} 43^{\prime} \mathrm{E}, 32^{\circ} 58^{\prime} \mathrm{N}$

Open site.

$110^{\circ} 46^{\prime} \mathrm{E}, 29^{\circ} 40^{\prime} \mathrm{N}$

Open site along a small river.
House remains, storage pits, kilns, protective ditches, burials; thousands of ceramic, stone, and bone

implements, including bone flutes; remains of domesticated rice grains and pig (or boar?), and more than 20 species of wild animals and plants.

Subterraneous houses, burials with grave goods, kiln, storage pits;

flaked and ground tools including axes and points; ceramic vessels;

\section{imprinted rice husk.}

On-the-ground, subterraneous, and piled dwellings, burials with very few grave goods, pottery with rice husks; flaked stone tools and large pebble tools; ground adzes and bone spades; wooden spades and drills;

thousands of rice grains, remains of ox, pig (?), deer, chicken (bird?), and fish, etc.; protective ditches found in Bashidang.
$8561-8332,8546-8411$ $8303-7964,7836-7587$

Institute of Archaeology, Henan Province 1999

7179-6912, 7018-6799

Estimated to be between 9500 and 7500 B.P. Pottery found in Pengtoushan is dated to between cal. 8946 and 5549 B.C.
Institute of Archaeology, CASS 1984, 1991.

Chen and Hedges 1994; Pei 1995, 2001. 
15,000 and 12,000 years ago (40). The rice husks are not directly dated, so cautions should be taken at this stage. However, as rice phytoliths have been found in the same layer, it is possible that rice was first exploited around 12,000 years ago, which is contemporary to that found in Xianrendong and Diaotonghuan (MacNeish et al. 1998; Zhao 1998).

By 8500 years ago, more prehistoric societies with rice remains occurred in the middle and lower Yangzi Basin, with Pengtoushan and Bashidang in the middle Yangzi and Shangshan in the lower Yangzi being the earliest (Tables 1 and 2). The archaeological assemblages dated prior to 10,000 and those dated from 9000 to 7000 years ago in the Yangzi Basin share some similarities, as pebble tools dominated both groups and pottery with cord mark is frequently found. It seems that there were cultural connections between the Upper Pleistocene and the early Holocene cultures in this region.

All the aforementioned sites have been reported before (i.e., Crawford and Shen 1998; Higham and Lu 1998; Lu 1999; MacNeish et al. 1998) except Shangshan, which is a new archaeological assemblage found in the lower Yangzi River Valley in 2001 (Jiang et al. 2003). While both Xianrendong and Yuchanyan are caves, Shangshan is an open site. Located at the lower Yangzi plain between Xianrendong/Diaotonghuan and the well-known Hemudu assemblage (Fig. 1), the vicinity of Shangshan is part of the fertile Yangzi Basin with rich water resources. Pile holes, ceramic pots and round-bottom cooking $f u$ (cauldrons), and stone and organic tools have been discovered here (Jiang et al. 2003). Many Shangshan potsherds were tempered with rice husks. The majority of reconstructible vessels are big basins flaring up from a small and flat bottom, with a loop handle near the bottom. The vessels are mainly plain, but some are decorated with cord mark, stamping, and incisions. The Shangshan toolkit consists of flaked stone balls, grinding slabs and hand stones, perforated stone implements, flaked pebble tools, and lithic abraders (Jiang et al. 2003).

The Shangshan perforated stone implements are similar to those found in South China, although their function is still not clear. Pebble tools have been widely found from the Yangzi River Valley to South China; flaked stone balls have been found in the middle and the lower Yangzi River Valley before, with the majority dated from the middle to the late Paleolithic (Wang 1997; Zhang et al. 2002). There seem to be some cultural similarities between the Shangshan toolkit and the local Paleolithic cultures.

By measuring the width and length of the rice husks, Jiang and his colleagues argued that the Shangshan rice was at the very early stage of being domesticated (Jiang et al. 2003). Radiocarbon dating tested on charcoal contained in potsherds by the laboratory of the Beijing University reveal absolute dates of $9610 \pm 160$, $8740 \pm 110,8620 \pm 160$, and $8050 \pm 110$ B.P. (uncalibrated) (Jiang et al. 2003). After calibration they fall within the range between 11,217 and 8650 years ago (Table 1). Apparently, the Shangshan assemblage is another important database for understanding the occurrence of incipient cultivation in the Yangzi Basin.

It seems that the tools and ceramics found in Xianrendong and Shangshan share some similarities, such as the dominance of pebble tools and coarse pottery built by slab building with cord mark (Table 1). However, there are also differences between the two: 
1. Small flaked lithic implements are found in Xianrendong but not yet in Shangshan.

2. Pebble spheres are found in Shangshan but not in Xianrendong.

3. Organic tools are important implements in Xianrendong but not in Shangshan. This, however, may be due to the acid soil and unfavorable preservation environment at Shangshan.

4. Potsherds in Xianrendong are tempered with minerals, but in Shangshan they are mixed with rice husk.

As the Xianrendong/Diaotonghuan data are still being studied and the excavation at Shangshan is still ongoing, the cultural relationship between the two assemblages remains unclear at the moment.

\section{RELATED GENETIC AND AGRONOMIC STUDIES}

Based on current research, at least three cereals were domesticated in China: rice (Oryza sativa L.), foxtail millet (Setaria italica [L.] Beauv.), and broomcorn millet (Panicum miliaceum L.). Recent genetic and agronomic studies have been focusing on the questions of the progenitors of domesticated millet and rice in China, as well as natural and human factors that may have influenced the evolutionary process of domestication.

Geneticists have argued that green foxtail (S. viridis [L.] Beauv.) is the wild ancestor of foxtail millet domesticated in China (Benabdelmouna et al. 2001; d'Ennequin et al. 2000; Nakayama et al. 1999). There are several major differences between the two species: foxtail millet produces many more seeds, has tougher rachis and far fewer branches, and has lost its dormancy (Lu 1998, 2002). Of these, the characteristic of fewer branches is controlled by genes and probably hormone biosynthesis (Doust et al. 2004:9049). Human interferences by selecting and cultivating plants of fewer branches (i.e., Taiwan Indigenous, Fogg 1983) must have accelerated the development of this characteristic. The genes controlling other characteristics of foxtail millet have also been investigated (Ichitani et al. 2003). Further studies on impacts of human interferences on the biological structures of the green foxtail are required for our understanding of how green foxtail was domesticated by cultivation.

The progenitor of broomcorn millet is not very clear. According to an isozymic analysis, the wild ancestor of broomcorn millet may be a wild grass that was given the same name as its domesticated counterpart (Panicum miliaceum L.) and is still widely distributed in the Yellow River Valley today (Jiang and Feng 1997 :74). However, it is also suspected that this wild grass may be a retrogressive subspecies of the domesticated broomcorn millet (75).

Another major domesticated cereal in China is rice. Generally speaking, there are two types of Asian wild rice related to rice farming: One is a perennial (Oryza rufipogon Griff.) and another is an annual type (O. nivara Sharma and Shastry). ${ }^{3}$ To date, there seems no consensus on whether they are two species or two variants of one species or on which one is the direct progenitor of the domesticated Asian rice (O. sativa L.) (e.g., Ahn 1993:16-17; Crawford and Shen 1998; Wang et al. 1998). 
Agronomists and geneticists seem to agree, however, that there are at least two subspecies of domesticated rice: the indica and the japonica (O. sativa indica and O. sativa japonica, respectively) (Ahn 1993; Wang et al. 1998). After analyzing 96 samples of wild rice and 885 samples of domesticated rice, Huang and her colleagues argue that there are probably two centers for the origin of rice farming in Asia: the japonica rice is domesticated in East/Southeast Asia and the indica rice in South Asia (Huang et al. 1996). This result seems to further support the hypothesis of a diphyletic evolution of domesticated rice in Asia, which was first proposed in the late 1940s by a Chinese agronomist (Sun et al. 2002). Further, DNA analysis indicates that the differentiation between indica and japonica rice occurred before rice was domesticated and that the perennial wild rice is likely the ancestor of japonica (Sato 1997, cited by Crawford and Shen 1998:864).

Samples from 21 populations of perennial wild rice (O. rufipogon) in mainland China were selected and subjected to allozyme variation and genetic structure analysis; of these, 14 populations were from Guangxi, 2 from Hunan, and the other 5 from Yunnan, Guangdong, Jiangxi, Fujian, and Hainan, respectively (Gao and Hong 2000). Samples collected in the present Guangxi and Guangdong Provinces of South China are reported to have the highest genetic diversity, while those from Fujian, also of South China, have the lowest genetic diversity (496). Samples collected in the present Yunnan, Hunan, and Jiangxi Provinces, all within the Yangzi Basin, have relatively lower genetic diversities. It is thus argued that South China is the center of genetic diversity of perennial wild rice in China (499). On the other hand, wild rice populations found in Yunnan, Jiangxi, and Hunan Provinces of the Yangzi Basin have more "primitive" phenotypic characteristics, such as "long anthers, purple stigmas, red long awns, black hulls," while those found in Guangdong and Guangxi of South China don't have these characteristics (Sun et al. 2002:5). Does this mean that the wild rice in the Yangzi Basin is more ancient than its counterpart in South China? Or is this due to the geographic isolation of the populations in the former? At present, these questions remain unanswered.

Nevertheless, this study illustrates different genetic structures of the wild rice in the Yangzi Basin and South China, which may result from a relatively long period of reproduction isolation between the two areas. Geneticists have also discovered genes that control the botanic characteristics of wild rice, such as seed shattering and dormancy. The former is at least controlled by genes on chromosome numbers $1,4,8$, and 11 , while the latter is controlled by various genes on 10 pairs of chromosomes (Bres-Patry et al. 2001; Cai and Morishima 2000, 2002). The domesticated characteristics of rice, such as tough rachis and shorter growth period, are all controlled by recessive alleles of these genes (Xiong et al. 1999). Apparently it was the mutation of these genes and human interference that facilitated the botanic evolution toward the speciation of domesticated plants (Rieseberg et al. 2002).

Genetic differences between wild rice populations may provide new light for our understanding of why incipient cultivation occurred in the Yangzi Basin instead of South China, although the latter is a more favorable habitat for the species. I have observed that the perennial wild rice in South China on average produces about 26.3 grains per panicle; yet the wild rice in the Yangzi River Valley produces 20-100 grains per panicle (Sun 1990), or an average of 60 grains, which 
is 128 percent more than its counterpart in South China. More grains per panicle means higher productivity, which is more appealing to prehistoric collectors and cultivators.

The causes of this higher productivity in the Yangzi Basin are not certain, but climate may be a factor here. The present winter in the Yangzi Basin is approximately $2-4{ }^{\circ} \mathrm{C}$ colder than that in South China (Chinese Academy of Science $1985: 106)$. The temperatures at around 12,000 to 10,000 years ago were lower than at present in both areas $(\operatorname{Li} 1998: 132-133,145-149)$. As wild rice is more susceptible to cold than domesticated species (Li et al. 1981:205), it would have been harder for the perennial wild rice to survive and reproduce by ratooning in the Yangzi Basin at that time. Did the wild rice in the Yangzi Basin adapt to a colder climate some 12,000 years ago by producing more seeds to ensure population reproduction? Did the higher productivity attract prehistoric collectors/cultivators in the Yangzi Basin? These are questions for further study.

In summary, genetic studies have provided data for the question of what has been domesticated, although the wild progenitors of broomcorn millet and rice remain unclear. Apparently the genetic and other scientific studies on millet are insufficient compared to rice. The reason for this imbalance is not clear, but it should be pointed out that millet is a far less important crop in China today, even in the Yellow River Valley (Chai 1999:4).

To answer the questions of why and how wild rice and millet were domesticated by cultivation, other approaches are required, including experiments on foraging, harvesting, and cultivation.

\section{DATA FROM EXPERIMENTS}

The experimental approach has been used in the Middle East, Mesoamerica, and America to investigate the questions of why and how agriculture originates (e.g., Anderson 1992; Flannery 1973; Harlan 1967; Hillman and Davies 1999). According to these experiments, productivity was an important impetus for prehistoric foragers to collect and cultivate the progenitors of wheat, barley, and maize.

In order to examine the productivity of collecting and cultivating the progenitor of foxtail millet and rice, I conducted harvesting and cultivation experiments of green foxtail in 1995 and 1999 (Lu 1998, 2002) and of rice in 1999 and 2000. According to the experiments, harvesting green foxtail is not very productive; nor is the incipient cultivation of this wild grass. The experiments on wild rice conducted in South China also have similar results.

The rice harvesting experiments used replicas of flakes of quartz and tektite, as well as knives made of freshwater shells. These are the most commonly found tools in the Yangzi Basin and South China dated from over 12,000 to 5000 years ago. Both have been hypothesized as cutting tools, with the shell knives being hypothesized for rice harvesting (MacNeish et al. 1998), but their functions need to be examined. Thus the experiments also provided reference for future functional analysis.

Since many scholars agree that the perennial wild rice (O. rufipogon) is either a direct or an indirect progenitor of domesticated rice in Asia (Ahn 1993; Wang et al. 1998), it was chosen as the experimental focus. The first harvesting experiment was conducted on 31 October 1999 at a site located at the northern suburb of 


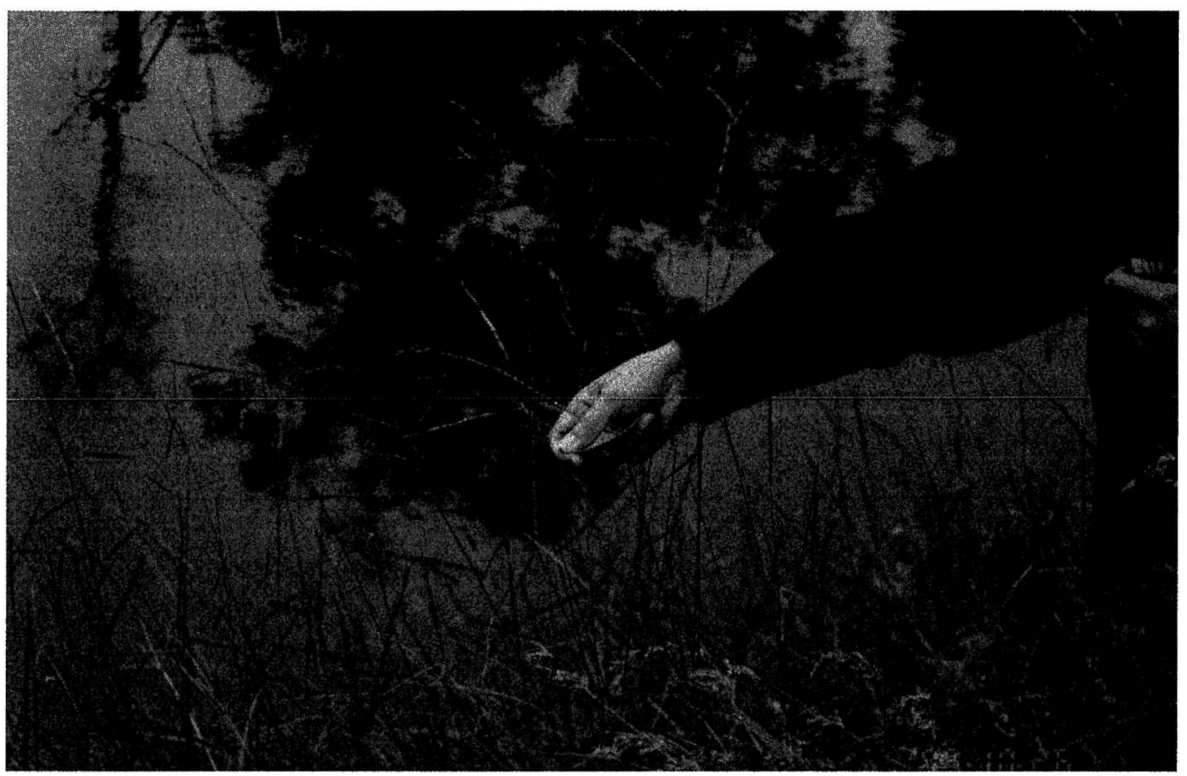

Fig. 2. Harvesting wild rice at $\mathrm{Wu} \mathrm{Xu,} \mathrm{Nanning} \mathrm{City,} \mathrm{South} \mathrm{China.}$

Nanning City, Guangxi Municipality, South China (Figs. 1, 2). A substantial quantity of wild rice was located in a pond measured to approximately $12 \mathrm{~m}$ in width and $14 \mathrm{~m}$ in length and was identified as perennial wild rice by a local agronomist (Leung Yaomao, personal communication). On the day of harvesting, the majority of the wild rice population was ripening, and many grains had already shattered.

Harvesting was first conducted by using a replicated shell knife to reap the panicles (Fig. 2), and a total of 414 panicles were gathered in 30 minutes. Then a replica tektite flake was used and another 220 panicles were collected in 15 minutes. The tektite flake seems slightly more efficient than the shell knife.

A total of 634 panicles were gathered within 45 minutes. One hundred panicles were randomly selected and counted, and the total ripe grains amounted to only 120 - or, on average, merely 1.2 grains produced from each panicle. In fact, many panicles bore no ripe grains at all when harvested, and the maximum quantity of ripe seeds on one panicle was only nine. Comparatively, a hundred panicles of domesticated rice (Oryza sativa japonica) growing in adjacent areas produce 82.1 edible grains per panicle on average, which is 68.4 times that of the wild rice.

To check the 1999 result, perennial wild rice was again harvested on 25 October 2000 in the southern suburb of Guilin City, Guangxi Municipality, South China. Only a small population of wild rice was located in that area. The result of the second harvesting experiment was similar: Only 169 grains were obtained from 129 panicles gathered, or 1.31 grains per panicle on average. A total of 300 wild rice grains were weighted, and the average weight per 100 grains ranged between 2.3 and 2.7 grams, similar to that of the domesticated subspecies japonica (O. sativa). 
Based on the experimental results, a 45-minute harvesting episode would have collected 796 ripe grains on average, which would weigh between 18.3 and 21.5 grams. A person in one hour can collect approximately 1061 grains, which will weigh between 24.4 and 28.64 grams. Assuming that an adult needed at least 250 grams to survive if this person relied on rice as the main source of starch, he or she would have had to spend between 8.7 and 10.2 hours to collect enough grains per day, plus other labor time to process (husking and winnowing) the wild rice grains. As the nutrition value of rice is mainly carbohydrate, people would need to gather other food for protein and fiber. Thus, a forager relying on rice for starch would have had to spend all day on gathering activitics in order to produce adequate food for one person (Table 3 ).

The very low productivity of wild rice in South China ${ }^{4}$ is mainly due to several factors. First, wild rice mainly relies on vegetative reproduction and produces only 20-50 seeds per plant, many of which are inedible husks. Second, the growth cycle of wild perennial rice is highly heterochronous, with the flowering and ripening season lasting for more than one month. Thus it is hard to collect many seeds in a day or two. Third, ripening seeds shatter in the muddy water due to the plants' fragile rachis, making collecting more difficult.

From 1999 to 2002, I also conducted gathering experiments on freshwater shellfish, wild yam, and bamboo root in South China. No tools are required for shellfish gathering except a knitted bamboo container. As the majority of shellfish live in shallow waters near the riverbanks, gathering is simply done by stepping into the water and picking up shells. For wild yam and bamboo roots, a flaked pebble point is required to dig up the plants. It takes about $10-15$ minutes to produce a pebble point, and the collecting returns are quite satisfactory (Table 3 ).

The results of these experiments suggest that, compared to harvesting wild rice, collecting shellfish, yam, and bamboo roots is more efficient and productive. A prehistoric forager needed to work only about two or three hours per day to survive on freshwater shellfish, wild yam, and bamboo root (Table 3).

To further investigate the process and production of cultivating wild rice, I have been conducting a cultivation experiment of Asian wild rice (O. rufipogon) in Hong Kong since 2000. Wild rice grains collected in South China were sown in the spring in shallow water ponds and left unattended until the grains ripened. This is to imitate the initial cultivation activity that might have been carried out by the prehistoric cultivators. The experiment reveals that the germination rate of wild rice can be as low as 17 percent, and the return is extremely low due to both seed shattering before fully ripe and the high rate of infertility of the grains. Out of the 30 grains of wild rice sown in April 2000, only 6 grains germinated, producing only 36 grains when harvested in November 2000. In other words, the productivity rate is only 1.2. Results of the following three years were similarly disappointing. These experiments demonstrate how unproductive is the incipient cultivation of wild rice.

All the aforementioned botanical characteristics - very low germinating rate, infertile and shattered grains - are typical of perennial wild rice (Xiong et al. 1999). The higher germination, fertility rate, and nonshattered grains of domesticated rice are the results of human selection and interference. A cultivation experiment conducted in the 1960s demonstrated that by presoaking seeds and shifting seedlings, as well as other farming techniques, changes in some of the botanical 
Table 3. Production Rates of Gathering Food in South China

\begin{tabular}{|c|c|c|c|c|c|}
\hline $\begin{array}{l}\text { CATEGORIES (AND } \\
\text { MAJOR NUTRITIVE } \\
\text { SUBSTANCE*) }\end{array}$ & $\begin{array}{c}\text { AVERAGE KCAL. PER IOO } \\
\text { GRAMS (COOKED BY } \\
\text { BOILING) }\end{array}$ & $\begin{array}{l}\text { TIME REQUIRED FOR } \\
\text { COLLECTING PER IOO } \\
\text { GRAMS }\end{array}$ & $\begin{array}{l}\text { ASSUMED DAILY INTAKE } \\
\text { (KCAL.) AND QUALITY }\end{array}$ & $\begin{array}{l}\text { TOTAL GATHERING TIME } \\
\text { REQUIRED FOR DAILY } \\
\text { INTAKE }\end{array}$ & $\begin{array}{l}\text { PRODUCTION RATE } \\
\text { (KCAL./HOUR) }\end{array}$ \\
\hline $\begin{array}{l}\text { Freshwater shells } \\
\quad \text { (protein) }\end{array}$ & $63.5 \mathrm{Kcal}$. & $\begin{array}{l}11.5 \text { minutes (average } \\
\text { of two runs) }\end{array}$ & 400 (630 grams) & 72.5 minutes & $331 \mathrm{Kcal} . /$ hour \\
\hline $\begin{array}{l}\text { Wild yam (starch, fiber, } \\
\text { protein, and vitamin) }\end{array}$ & $113 \mathrm{Kcal}$. & $\begin{array}{l}\text { 3-7 minutes (depending } \\
\text { on the soil structure, } \\
\text { size of the root, and } \\
\text { tools) }\end{array}$ & 800 (708 grams) & 21-49.6 minutes & $\begin{array}{l}\text { 968.5-2260 Kcal./hour } \\
\text { (time for producing } \\
\text { tools not included) }\end{array}$ \\
\hline $\begin{array}{l}\text { Bamboo root (protein } \\
\text { and fiber) }\end{array}$ & $20 \mathrm{Kcal}$ & $\begin{array}{l}4.1 \text { minutes (average of } \\
\text { two runs) }\end{array}$ & 200 (1000 grams) & 41 minutes & $\begin{array}{l}288 \mathrm{Kcal} . / \text { hour } \\
\text { (excluding time for } \\
\text { tool production) }\end{array}$ \\
\hline Subtotal: & & & 1400 Kcal. & $\begin{array}{l}\text { 134.5-163.1 } \\
\text { minutes, or } \\
\text { between } 2-3 \\
\text { hours }\end{array}$ & \\
\hline $\begin{array}{l}\text { Wild rice (starch, fiber, } \\
\text { minor protein) }\end{array}$ & $341 \mathrm{Kcal}$. & $\begin{array}{l}\text { 209-246 minutes } \\
\quad \text { (average of two runs) }\end{array}$ & 852 (250 grams) & $523-615$ minutes & $83.2-97.66 \mathrm{kcal} . /$ hour \\
\hline
\end{tabular}

* Source: Institute of Nutrition and Food Health (1991). 
characteristics of wild rice were visible in several generations, including larger grains and a lower percentage of seed shedding (Oka and Morishima 1970:357). However, it is unlikely that the incipient cultivators in the prehistoric Yangzi Basin would have known such techniques. Hillman and Davies (1999) have argued that the change in the botanical characteristics of wild plants could be much slower if "primitive methods" were used for cultivation. My own cultivation experiments of wild rice and green foxtail support this argument ( $\mathrm{Lu}$ 2002).

As the majority of domesticated characteristics are controlled by recessive genotypes (Xiong et al. 1999) and the evolution and development of domesticated genotypes might have resulted from dynamics between genetic structures and the external environment (Kang 2004), the evolution from wild to domesticated cereals can be very complicated, and the productivity at the incipient stage of cultivation must be quite low. Therefore, the early cultivators must also have relied on other resources. The large quantities and varieties of wild animals and plants found in archaeological assemblages dated to 10,000 years or earlier (Table 1) indicate that the possibly incipient cultivators of millet and rice were hunters and gatherers.

If the initial cultivation of wild grasses was so unproductive, why did the incipient cultivators continue? Cultivation experiments also suggest that no particular attention was required at the initial stage; nor was sedentism ( $\mathrm{Lu} 2002)$. As initial cultivation required little labor input, yet could still produce some extra food in the meantime, the prehistoric cultivators might have maintained this economic activity.

Thus, incipient cultivation was probably a supplementary or even a leisure activity, without much expectation for return. The incipient cultivators were mainly hunters and gathers and were only "part-time" or "occasional" farmers, until the production of cultivation increased to a certain level and/or until the natural floral and faunal resources were depleted by their foraging activities. This process in China's context might have been similar to that proposed by Flannery in Mesoamerica (Flannery 1973:299).

\section{ETHNOGRAPHIC STUDY}

Ethnographic study relating to the origin of agriculture has been focused on the questions of where and how agriculture originated in China, as well as on what was cultivated. Several scholars have argued that agriculture in China's context might have initiated in the mountains or high plateaus, where the present-day ethnic minorities commenced their cultivating activities when they were still foragers (e.g., $\mathrm{Li}$ and $\mathrm{Lu}$ 1981; Tao 1994). This, however, is unsound, for the Han and other peoples pushed the ancestors of many minorities in China into mountainous areas within the historical epoch. There is no evidence that they preferred mountains to farming activities. In addition, it is risky to assume that the present-day cultivation of these minorities reflects the prehistoric past of a few thousand years ago.

Based upon ethnographic data, Li Fu-qiang (1998) argued that roots (yam, taro, etc.) were probably the earliest cultivars in South China. Macroremains of plant roots and taro residue have been found in Zengpiyan, Guangxi, South China (Institute of Archaeology CASS et al. 2003). However, we are not sure 
whether the plant roots found in Zengpiyan are wild or domesticated. More work is required to test this hypothesis.

Finally, Chen (1991) proposed that slash-and-burn agriculture-still practiced by minorities in southern and southwestern China until the 1950 s-was probably the earliest cultivating technique in China. This is also possible, but we need to obtain much more data on prehistoric farming techniques before reaching any conclusion.

Ethnographic data may provide insight for us to investigate the techniques, tools, and other facilities of the incipient cultivators in prehistoric China, but as cultures change constantly, we must use caution when we refer to these data.

\section{DISCUSSION}

Price and Gebauer $(1995: 6)$ argued that "the most important factors in the transition (from foraging to farming) ... include, in order of suggested importance, available protodomesticates, human sedentism, higher population density, resource abundance, geographic and/or social constraints, processing and harvesting technology, storage, and wealth accumulation." They also considered that there should be "a general explanation" for the occurrence of agriculture in several places of the world (5), a view that differs from Flannery $(1973: 272)$.

In China's context, the protodomesticates of millet and rice are widely distributed, facilitating the incipient cultivation of these grasses. Both millet and rice seem to have been cultivated on plains in the temperate zones with fertile soil and relatively rich resources-namely, North China and the Yangzi Basin.

On the other hand, we should also notice that favorable environments do not necessarily lead to the occurrence of cultivation. South China is warmer and moister than North China and the Yangzi Basin, with wild rice and highly abundant natural resources (Chinese Academy of Science 1985:104-112). Yet archaeological data indicate that cereal cultivation did not occur in this region until approximately 7000 to 6500 years ago, which was likely a result of cultural contact with and expansion from the Yangzi Basin (Fu 2003). Clearly, protodomesticates and other environmental factors were important for the occurrence of cultivation in China, but they are not the absolute determining factors. While incipient cultivation might have occurred "in areas of relatively abundant resources" (Price and Gebauer 1995:7), it may not occur in areas of very abundant resources, such as South China, where foraging might be a more efficient way of life ( $\mathrm{Lu} 2003$ ).

Archaeological discoveries made in Ohalo II, Abu Hureyra, and other EpiPaleolithic and early Neolithic sites in the Middle East suggest that a broad spectrum subsistence strategy was practiced in this area at the terminal Pleistocene (e.g., Bar-Yosef and Meadow 1995), including the collecting of wild grass seeds and incipient cultivation before 11,000 years ago. Hillman et al. (2001:383) have argued that the beginning of cultivation in Abu Hureyra was due to the decline of wild grasses that had been a staple food of the local residents for centuries and that the decline was caused by the sudden deterioration of climate at around 13,000 years ago. However, in China's context, experimental data suggest that wild rice was not productive enough to be a staple food for the local peoples. On the other hand, the seasonality of natural resources might have been an important factor. In temperate areas where resources were not abundant in the winter, the storable 
grass seeds could have been very appealing to the prehistoric foragers and could be a major reason for the beginning of cultivation (Bellwood 1996; Yan 1992).

According to Price and Gebauer (1995:6), sedentism is the second important factor for the transition to farming. If sedentism is defined as a lifestyle "based around a single main settlement rather than involving moving camp at regular intervals" (Darvill 2003:383) and the presence of houses, kilns, protective ditches, and cemeteries can be taken as indicators of sedentism, then there is no evidence to date to suggest that the incipient cultivators in China were sedentary. No house remains, cemeteries, or remains of other facilities such as storage or kilns have been reported (Table 1). In the Yangzi Basin, the Xianrendong and Diaotonghuan rice collectors/cultivators lived in caves; so did the Yuchanyan people. Pile holes have been reported from Shangshan in the Yangzi Basin, but the date and the contexts of these holes are not clear at the moment.

Of course, house remains cannot be used as the only criterion to judge the mobility of the prehistoric peoples in North China and the Yangzi Basin. Unfortunately, this issue cannot be discussed further due to the lack of published details. On the other hand, experiments indicate that constant attention was not required at the initial stage of cultivation ( $\mathrm{Lu} 2002$ ); thus, sedentism was not a prerequisite, at least not in the Yangzi Basin (we cannot be certain yet whether the prehistoric groups 10,000 years ago in North China were cultivators).

One of the most significant consequences of cultivation is to reduce mobility. Murdock rated the mobility of hunters and gatherers to four scales based on ethnographic data: full migratory, seminomadic, semisedentary, and relatively permanent sedentary (Murdock 1967:159). Binford (1980) constructed two settlement systems for the hunters and gatherers: the "foragers," who seem fully or seminomadic, and the "collectors," who seem seminomadic or semisedentary based on Murdock's rating. Based on archaeological, experimental, and ethnographic data, the incipient cultivators in China were likely seminomadic or semisedentary or "collectors" living on various wild species, with cultivation as a supplementary subsistence strategy. As they had to stay within certain "territory" to harvest their crops (Lu 2002), however, cultivation might have reduced their mobility and probably caused an increase in population and the depletion of wild resources. If the incipient cultivators could no longer easily go to other "territory" to forage, cereal cultivation might have become more important. Consequently, efforts must have been made to increase the productivity, including using fertilizers and other farming techniques, probably by trial and error. As more techniques were applied and the productivity increased, cereal cultivation became more important and farmers needed to stay close to their fields, which would have eventually led to the full sedentary subsistence strategy of agriculture. It was probably the reduced mobility, gradually increased population, and the depletion of wild resources that pushed the early cultivators toward sedentism and farming. This is different from the cultural development in the Middle East (i.e., Bar-Yosef 2003).

Of course, much more work is required to test this hypothesis in China. We need to investigate the "catchment area" of the archaeological assemblages dated prior to 10,000 years ago, to examine the mobility and settlement patterns, and to study whether cultivation was practiced by archaeological assemblages dated to 10,000 years or earlier, particularly those in North China.

Cohen has argued that overpopulation is a major factor for the origin of agri- 
culture (1977). Did population pressure play a role in the occurrence of cereal cultivation in China? Current data do not seem to illustrate sedentary occupation of large communities prior to 9000 years ago in China, particularly in caves in the Yangzi River Valley (Table 1), which probably can accommodate groups only between 20-30 persons. The distribution of groups dated to this period is not dense, either. There is no evidence to indicate that overpopulation was a major factor in China.

There is also no evidence to suggest the accumulation of wealth (Price and Gebauer 1995:6) prior to the occurrence of cereal cultivation, as the prehistoric groups dated between 13,000 and 9000 years ago in China seem to be quite egalitarian. Their settlements are either small-scale open sites (e.g., Shizitan) or restricted in caves (Table 1). For example, a total of 25 finding places have been found in Shizitan within an area of $15 \mathrm{~km}^{2}$, and these are considered the remains of seasonal camps (National Bureau of Antiquity Management 2004; Shi et al. 2002). Further, the majority of artifacts found in the archaeological assemblages dated prior to 9000 years ago are daily items for basic needs (Tables 1 and 2). So far, no exotic or labor-intensive items have been discovered, except possibly the shell necklace found in Donghulin, which was identified as made from shells found only on the eastern coast today (Zhao et al. 2003), suggesting certain trade and/or cultural contact between the Donghulin residents in North China and groups in the coastal areas.

Burial analysis is often an important approach for us to understand the social structure. However, there is only one burial reported in Donghulin, North China, and it is without details (Zhao et al. 2003). To date, we don't have evidence for the existence of stratified societies prior to the occurrence of cereal cultivation in China. This is in contrast to the local farming societies dated to after 9000 years ago, which are characterized by large permanent settlements up to thousands of square meters and labor-intensive items with possibly symbolic meanings such as bone flutes, tortoise shells (at Jiahu), jade, and ivory items (at Xinglonggou and Hemudu) (Table 2). All the assemblages listed in Table 2 represent several to dozens of similar archaeological assemblages found in adjacent areas, indicating constant cultural changes and intergroup contacts, as well as increased populations. Apparently, agriculture caused a lot of cultural changes in prehistoric China.

Regarding "processing and harvesting technology" (Price and Gebauer $1995: 6$ ), the grinding slabs and cutting tools found in Nanzhuangtou and Shizitan could be used for cereal processing and harvesting. Flaked stone and organic implements were used for the rice collectors and cultivators in Diaotonghuan (MacNeish et al. 1998; Zhao 1998), though many of them are multifunctional, with the possibility that the shell knives were used for rice reaping (MacNeish et al. 1998:18-19), a hypothesis yet to be tested by use-wear and other analysis.

Another important technology related to cereal cultivation in China is the manufacturing of pottery. In the Middle East, ceramic technologies emerged after the appearance of farming (Bar-Yosef 2003). In China, both foragers and possible cultivators engaged in ceramic manufacture as early as 11,000-10,000 years ago in both North China (Guo and Li 2000; Zhao et al. 2003) and the Yangzi Basin (Yuan 2000; Zhang 2000) and perhaps as early as 12,000 years ago in South China (Fu 2003; Lu 2005) (Table 1). 
Early pottery has also been found in the Japanese archipelago dated between 15,000 and 12,000 years ago (Takashi 2000) and in Siberia between 12,000 and 10,000 years ago (Zhushchikhovskaya 1997). In East Asia, pottery was used by foragers in different geographic regions for processing various food ingredients from fish to nuts (Crawford 2005; Takashi 2000; Zhushchikhovskaya 1997), probably including cooking grass seeds, shells, and storage (Lu 1999, 2005).

The majority of vessels found in archaeological assemblages dated over 10,000 years ago in North China and the Yangzi Basin are round-bottom cooking cauldrons. After 9000 years ago, ceramic assemblages of the sedentary farmers in these two regions were much diversified, with various decoration motifs and paintings. On the other hand, ceramics used by foragers in South China from 12,000 to 8000 years ago changed little in terms of typological variation and decoration. Apparently the invention of pottery was not directly associated with the beginning of plant cultivation, although pottery vessels were probably processing and

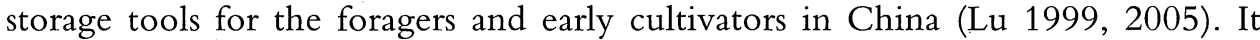
was sedentary farming and other cultural changes such as labor division that stimulated and facilitated the development of ceramic techniques and diversities ( $\mathrm{Lu}$ 1999, 2005).

As discussed above, experimental data suggest that very little technique was required at the initial stage of cultivation, although the return could be very low. The incipient cultivators must have also hunted, fished, and gathered to survive. Thus the subsistence strategy of the early cultivators in China must have covered a broad spectrum.

In prehistoric and historic China, hunting and gathering were not completely abandoned even in well-developed farming societies. In Hemudu, 58 species of wild animals including fish and freshwater shellfish have been identified, associated with large quantities of domesticated rice, oak seeds (Quercus sp.), water chestnut (Trapa sp.), and fruit of the lapsi tree (Choerospondias axillaris) (Institute of Archaeology, Zhejiang Province 2003). Similar animal and plant remains other than cereals have also been found in Jiahu, Pengtoushan, Bashidang, and other farming societies (Pei 1995), as well as in the Bronze Age Zaojiaoshu dated to 3660 years ago (Archaeology Team of Luoyang City 2002). Historical documents also record that farmers in ancient China often collected various wild plants and hunted wild animals to supplement their need for food (You 1987). It is very likely that the transition from foraging to farming in China was a transition from a subsistence strategy system mainly based on foraging to a system mainly based on cereal cultivation, with the importance of farming varying in different places, at different times, and in different cultures. We may have overemphasized the occurrence of agriculture as a revolution of subsistence strategy and ignored the fact that such an evolutionary process - which involved both human (biological and cultural) and natural species (plants and animals) - was probably a more gradual, complicated, and long-lasting process that we previously thought.

\section{CONCLUSION}

Although significant progress has been made over the past eight decades, we must admit that we still have much to learn about the transition from foraging to farming in China, as archaeological data dated between 12,000 and 10,000 years ago 
are very scanty and the majority of these data are not published. However, the new data discovered in the last ten years or so, plus experimental results, still give us some insight into this issue. The hypothesis, based on current data, is that incipient cereal cultivation in North China and the Yangzi Basin occurred approximately 11,000 to 10,000 years ago when the palaeoclimate improved after the Last Glacial Maximum and the Younger Dryas. It occurred in temperate areas where people lived with seasonally fluctuated resources, not in subtropical areas (i.e., South China) with very abundant and year-round resources.

In addition, the incipient cultivators seem to have been small groups of seminomadic or seasonal "collectors" (Binford 1980; Murdock 1967) who scattered over the vast areas of North China and the Yangzi Basin. They first collected and then cultivated the progenitors of domesticated cereals (i.e., green foxtail in North China and wild rice in the Yangzi Basin). These people lived in open, probably seasonal camps in North China and caves in the Yangzi Basin. Their subsistence strategies are broad spectrum, as they lived on various wild plants and animals.

Small flakes and microblades seem to be part of the toolkits of these people, some of which might have served as harvesting tools in North China (Lu 2001) associated with grinding slabs for grass seed processing. Tools for rice cultivation in the Yangzi Basin are not certain at this stage, but it should be pointed out that large quantities of wooden and bone implements for cultivation have been found in the prehistoric farming societies in the Yangzi Basin, so it is possible that the incipient cultivators in the Yangzi might have used organic tools, too. Finally, the incipient cultivators also produced pottery and probably used it as a tool for cooking grass seeds and storage ( $\mathrm{Lu} \mathrm{1999,2005).}$

Of course, many questions remain concerning climatic change, timing, locations, and consequences of incipient cultivation. Significant palaeoclimatic and palaeoenvironmental changes marked the transition from the terminal Pleistocene to the early Holocene in China; these might have stimulated the collecting of wild grasses at the terminal.Pleistocene and facilitated the occurrence and expansion of farming in the early Holocene. We do not know, however, the detailed processes and the microclimatic changes at individual sites that were occupied between 12,000 to 10,000 years ago in North China and the Yangzi River Valley. Nor are we sure precisely when cultivation began in North China. Foxtail and broomcorn millets and rice are evidently the earliest cultivars in China, but we are not certain of the progenitors of the latter two, nor by what techniques or after how long these grasses were domesticated, although experiments suggest that this process is likely to be a very long one. Farming groups relying on different cultivars and using different material cultures lived in North China and in the Yangzi River Valley; whether incipient cultivation began in one area and radiated to the other, or whether it began concurrently in two core centers, remains unclear.

Identifying causes for these changes also remains difficult. We cannot find evidence of population pressure in China's context so far; nor can we identify traces of social stratification, competition, or "big men" to explain why the transition to farming occurred (Gebauer and Price 1992:2). In addition, what were the social structures of the Upper Pleistocene foragers and cultivators? Is geographic location relevant to the beginning of cultivation activity, and if so, how? What is the 
relationship between animal domestication and farming in China's context? Did the early cultivators in the Yangzi River Valley abandon their caves and move to open lands for farming after 10,000 years ago, and if so, why and how? All the aforementioned questions require much more work, and we need to search for new data and to use multidisciplinary approaches to test the above hypothesis.

Thus, is it possible to offer one general explanation on the origins of agriculture in different parts of the world? Is there a universal pattern for the development of prehistoric human cultures? Archaeological and experimental data from China to date do not seem to support these arguments. As human beings living in different environments and making their decisions based on their own cultures, it is more likely that the prehistoric transitions from foraging to farming in the world took various pathways and that the cultural developments of prehistoric peoples are diversified.

\section{ACKNOWLEDGMENTS}

The work described in this paper was substantially supported by a grant from the Research Grants Council of the Hong Kong Special Administrative Region, China (Project No. CUHK4196/02H), and partially supported by a 2004 Direct Grant from the Faculty of Social Science of the Chinese University of Hong Kong (Project No. 2020804). I am very grateful for the financial support I received. I would also like to sincerely thank the three reviewers for their comments and Dr. Miriam Stark and Ms. Suzanne Finney for their painstaking efforts to edit the manuscript.

\section{NOTES}

1. In this paper, "China" refers to the geographic landmass called China today.

2. In this paper, "incipient cultivators" are defined as prehistoric people who cultivated wild or transspecies between wild and domesticated grasses on a regular basis, whose techniques were rudimentary, and who might have remained seminomadic foragers. Archaeological assemblages of the incipient cultivators should contain rich animal and grass seed remains, including probably both wild and domesticated grass seeds. The Xianrendong/Diaotonghuan group can be defined as incipient cultivators in China's context.

3. The taxonomic classification of wild and domesticated rice seems quite complicated. According to Ahn (1993:17), some scholars consider that O. sativa L. f. spontanea is also a wild relative of the domesticated rice, while others consider it as a weed. For a comprehensive review, please see Ahn 1993.

4. The wild rice in the Yangzi River Valley seems to bear more seeds, but as the surviving population there is so small today, it has been preserved for agronomic and genetic study only and cannot be used for harvesting experiments.

\section{REFERENCES}

AhN, SUNG-MO

1993 Origin and Differentiation of Domesticated Rice in Asia: Review of Archaeological and Botanical Evidence. Ph.D. diss. University of London.

Anderson, Patricia C., ed.

1992 Prehistorie de L'agriculture. Paris: CNRS Press.

ANDERSSON, JOHAN G.

1929 Children of the Yellow Earth. London: Kegan Paul, Trench, Trubner.

Archaeological Team of Luoyang City

2002 Luoyang Zaojiaoshu (Zaojiaoshu Assemblage in Luoyang). Beijing: Cultural Relics Publishing House. 
BAR-Yosef, Ofer

2003 The Natufian culture and the early Neolithic: Social and economic trends in Southwestern Asia, in Examining the Farming/Language Dispersal Hypothesis: 113-126, ed. P. Bellwood and C. Renfrew. Cambridge: McDonald Institute Monographs.

Bar-Yosef, Ofer, and Richard H. Meadow

1995 The origin of agriculture in the Near East, in Last Hunters, First Farmers: New Perspectives on the Prehistoric Transition to Agriculture: 39-94, ed. D. T. Price and A. B. Gebauer. Santa Fe, NM: School of American Research Press.

Bellwood, Peter S.

1996 The origins and spread of agriculture in the Indo-Pacific region: Gradualism and diffusion or revolution and colonization? in The Origins and Spread of Agriculture and Pastoralism in Eurasia: 465-498, ed. David R. Harris. London: UCL Press.

2005 The First Farmers: Origins of Agricultural Societies. UK: Blackwell Publishing.

Bellwood, Peter S., and Colin Renfrew, eds.

2003 Examining the Farming/Language Dispersal Hypothesis. Cambridge: McDonald Institute Monographs.

Benabdelmouna, A., M. Abirached-Darmency, and H. Darmency

2001 Phylogenetic and genomic relationships in Setaria italica and its close relatives based on the molecular diversity and chromosomal organization of $5 \mathrm{~s}$ and $18 \mathrm{~s}-5.8 \mathrm{~s}-25 \mathrm{~s}$ rDNA genes. Theoretical and Applied Genetics 103:668-677.

BINFORD, LEWIS R.

1980 Willow smoke and dog's tails: Hunter-gatherer settlement systems and archaeological site formation. American Antiquity 45:4-21.

Bres-Patry, C., M. Lorieux, G. Clemment, M. Bangratz, and A. Ghesqueiere

2001 Heredity and genetic mapping of domestication-related traits in a temperate japonica weedy rice. Theoretical and Applied Genetics 102:118-126.

CaI, H. W., and H. Morishima

2000 Genomic regions affecting seed shattering and seed dormancy in rice. Theoretical and Applied Genetics 100:840-846.

2002 QTL clusters reflect character associations in wild and cultivated rice. Theoretical and Applied Genetics, online publication.

ChAI, YAN, ED.

1999 Mizi (Broomcorn Millet). Beijing: Science Press.

Chen, Tiemei, and R. E. Hedges

1994 Pengtoushan deng yizhi taopian he woguo zuizao shuidao yicun de jiasuqi zhipu $\mathrm{C}^{14}$ cenian (AMS radiocarbon dating of pottery from Pengtoushan and Hujiawuchang sites and the earliest rice remains in China). Wen $W u 3: 88-94$.

Chen, Wen-HuA

1991 Zhongguo Nongye Kejishi Tuji (Atlas of the History of Agricultural Technology in China). Beijing: Agriculture Press.

Chen, Zong-yu, Ji-Xiang Qi, Jian-ming Xu, Jia-ming Xu, Hao Ye, and Yun-Ju Nan

2002 Palaeoclimatic interpretation of the past $30 \mathrm{ka}$ from isotopic studies of the deep confined aquifer of the North China Plain. Applied Geochemistry 18(7): 997-1009.

Chinese Academy of Agronomy

1986 Zhongguo Daozuoxue (Rice Agriculture of China). Beijing: Agriculture Press.

Chinese Academy of Science

1985 Zhongguo Ziran Dili (Physiography of China). Beijing: Science Press.

COHEN, MARK N.

1977 The Food Crisis in Prehistory: Overpopulation and the Origins of Agriculture. New Haven: Yale University Press.

Crawford, Gary W.

1992 Prehistoric plant domestication in East Asia, in The Origin of Agriculture: An International Perspective: 7-38, ed. W. Cowan and P. J. Watson. Washington: Smithsonian Institution Press.

2005 East Asian plant domestication, in Archaeology of Asia: 77-95, ed. Maria Stark. Oxford, UK: Oxbow Books. 
Crawford, G. W., and Shen Chen

1998 The origins of rice agriculture: Recent progress in East Asia. Antiquity 72:858-866.

DARVILL, Timothy

2003 Concise Dictionary of Archaeology. Oxford, UK: Oxford University Press

Diamond, Jared, and Peter S. Bellwood

2003 Farmers and their languages: The first expansions. Science 300:597-603.

Donghulin Archaeological Team

2003 Beijing xinshiqi zaoqi kaogu de zhongyao tupuo (Important breakthrough of the early Neolithic archaeology in Beijing). Zhongguo Wenwubao (Chinese Antiquity News), 7 November, front page.

Doust, Andrew N., Katrien M. Devos, Michael D. Gadberry, Mike D. Gale, and Elizabeth

A. KellogG

2004 Genetic control of branching in foxtail millet. PNAS 101(24) : 9045-9050.

d'Ennequin, M. le Teierry, O. Panaud, B. Toupance, and A. Sarr

2000 Assessment of genetic relationships between Setaria italica and its wild relative $S$. viridis using AFLP markers. Theoretical and Applied Genetics 100(7):1061-1066.

FLANNERY, KENT V.

1973 The origins of agriculture. Annual Review of Anthropology 2:271-310.

FOGG, WAYNE H.

1983 Swidden cultivation of foxtail millet by Taiwan Aborigines: A cultural analogue of the domestication of Setaria italica, in The Origins of Chinese Civilization: 95-115, ed. D. N. Keightley. Berkeley: University of California Press.

Fu, XIAN-GUO

2003 Guangxi diqu shiqian wenhua fazhan xulie chulun (Prehistoric cultural developments in Guangxi), in Taoli Chengxi Ji-Qingzhu An Zhimin Xiansheng 80 Shouchen (Collected Articles to Celebrate the 80th Birthday of Prof. An Zhimin): 194-204, ed. Tang Chung and Chen Xingcan. Hong Kong: Local Press Ltd.

GAO, L. Z., AND S.G.D. HonG

2000 Allozyme variation and population genetic structure of common wild rice Oryza rufipogon Griff. in China. Theoretical and Applied Genetics $101: 494-502$.

Gebauer, A. B., and D. T. Price

1992 Transition to Agriculture in Prehistory. Madison, WI: Prehistory Press.

Glover, Ian C., and Charles F. W. Higham

1995 New evidence for early rice cultivation in South, Southeast and East Asia, in The Origins and Spread of Agriculture and Pastoralism in Eurasia: 413-441, ed. David R. Harris. London: UCL Press.

GuO, RUi-HAI, AND JUn Li

2000 Cong Nanzhuangtou yizhi kan huabei diqu nongye he taoqi de qiyuan (The Nanzhuangtou assemblage and the origin of agriculture and pottery in north China), in Daozuo, Taoqi he Doushi de Qiyuan (The Origins of Rice Agriculture, Pottery and Cities): 51-64, ed. Yan Wenming and Y. Yoshinori. Beijing: Cultural Relics Publishing House.

HARLAN, JaCK R.

1967 A wild wheat harvest in Turkey. Archaeology 20(1):197-201.

He, Y., Wilfred H. Theakstone, Zhong-lin Zhang, Dian Zhang, Tan-dong Yao, Tuo Chen, Yong-PIng Shen, AND Hong-Xi PANG

2004 Asynchronous Holocene climatic changes across China. Quaternary Research 61(1):52-63.

Higham, Charles

1995 The transition to rice cultivation in Southeast Asia, in Last Hunters, First Farmers: New Perspectives on the Prehistoric Transition to Agriculture: 127-155, ed. D. T. Price and A. B. Gebauer. Santa Fe, NM: School of American Research Press.

Higham, Charles, and Tracey L.-D. Lu

1998 The origins and dispersal of rice cultivation. Antiquity 72(278):867-877.

Hillman, Gordon, and M. S. Davies

1999 Domestication rate in wild wheats and barley under primitive cultivation, in Prehistory of Agriculture: New Experimental and Ethnographic Approaches: 70-102, ed Patricia Anderson. Los Angeles: UCLA Press. 
Hillman, Gordon, Robert Hedges, Andrew Moore, Susan Colledge, and Paul Pettitt

2001 New evidence of late glacial cereal cultivation at Abu Hureyra on the Euphrates. The Holocene 11(4): 383-393.

Ho, Pingti

1969 Huangtu he Zhongguo Nongye de Qiyuan (Loess and the Origin of Chinese Agriculture). Hong Kong: Chinese University of Hong Kong Press.

Huang, Yan-HONG, Hong-Wei CaI, AND Xiang-Kun Wang

1996 Yazhou zaipeidao fensan qiyuan de yanjiu (The diversified origin of rice farming in Asia), in Zhongguo Zaipeidao Qiyuan yu Yanhuai Yanjiu Zhuanji (The origin and evolution of rice farming in China): 92-100, ed. X. K. Wang and C. Q. Sun. Beijing: Agricultural University of China Press.

Ichitani, Katsuyuki, Kendo Nagao, Yukihiro Narita, Kenji Fujikawa, Miki Samejima, Satoru Taura, and Muneharu Sato

2003 Genetic analysis of tillering and other agronomic characters in foxtail millet (Setaria italica (L.) P. Beauv.) using the progeny from the cross between the two diverse strains, Gai 53 and Kuromochi. Memoirs of the Faculty of Agriculture, Kagoshima University 38(47):27-39.

Institute of Archaeology, CASS (Chinese Academy of Social Science)

1984 Xinzhongguo de Kaogu Faxian he Yanjiu (Archaeological Discoveries and Research in New China). Beijing: Cultural Relics Publishing House.

1991 Zhongguo Kaoguxue zhong Tanshisi Niandai Shujuji (C ${ }^{14}$ Dates of Chinese Archaeology). Beijing: Cultural Relics Publishing House.

Institute of Archaeology, CASS, Guangxi Archaeological Team, Zengpiyan Museum and Guilin Archaeological Team

2003 Guilin Zengpiyan (The Zengpiyan Cave in Guilin). Beijing: Cultural Relics Publishing House.

Institute of Archaeology, Henan Province

1999 Wuyang Jiahu (The Jiahu Assemblage in Wuyang County). Beijing: Science Press.

Institute of Archaeology, Zhejiang Province

2003 Hemudu (Monograph of Hemudu). Beijing: Cultural Relics Publishing House.

Institute of Nutrition and Food Health

1991 Food Contents. Beijing: People's Health Press.

JIANG, Ji-YUN, AND BAI-LI FENG

1997 Mizi de qiyuan he yanbian (The origin and evolution of broomcorn millet), in Mizi (Broomcorn Millet): 71-77, ed. Yan Cai. Beijing: Chinese Agriculture Press.

JiAng, Le-Ping, JiAn-ming Zheng, Shun-gan Rui, and Yun-fer Zheng

2003 Zhejiang pujiangxian faxian jujin wannian zuoyou de zaoqi xinshiqi shidai yizhi (An early Neolithic site dated to approximately 10,000 B.P. found in Pujiang County, Zhejiang Province). Zhongguo Wenwubao (Chinese Antiquity News), 17 November, front page.

Jiang, Qin-hua, And Dolores R. Piperno

1999 Environmental and archaeological implications of a late Quaternary palynological sequence, Poyang Lake, Southern China. Quaternary Research 52:250-258.

Kang, Manjit S.

2004 Breeding: Genotype-by-environment interaction, in Encyclopedia of Plant and Crop Science: 218-221, ed. Robert M. Goodman. New York: Marcel Dekker, Inc.

LI, FU-QIANG

1998 Manhuang Daoxiang-Zhuangzu Nonggeng Wenhuan (Agricultural Culture of the Zhuang Nationality). Hong Kong: Tianma Press.

Li, Pan, And Xun Lu

1981 Nongye qiyuan yu shandi kao (On the origins of agriculture in hilly area). Nongye Kaogu (Agricultural Archaeology) $1: 21-31$.

Li, Taigui, R. M. Visperas, and B. S. Vergara

1981 Correlation of cold tolerance at different growth stages in rice. ACTA Botanica Sinica 23(3): 203-207.

LI, WEN-YI

1998 Zhongguo Disiji Zhibei yu Huanjing (Quaternary Environment and Vegetation in China). Beijing: Science Press. 
Liu, Jian-guo, Xiao-bing Jia, Ming-hui Zhao, Guang-lin Tian, and Guo-tian Shao

2004 Xinglonggou juluo yizhi 2003 nian fajue xinchenguo (New discoveries in the 2003 field season at Xinglonggou). Zhongguo Wenwubao (China Antiquity News), 19 March, front page.

LiU, JiN-LiNG, AND William ChANG

1996 Gengju baofen ziliao tulun Changjiang sanjiaozhou diqu 12,000 nian yilai de huanjing bianqian (A reconstruction of the palaeoenvironment of the Yangzi delta in the last 12,000 years based upon pollen data). Gushengwu Xuebao (ACTA Palaeontologica Sinica) $35(2): 136-153$.

LIU, LI

2004 Wild and domesticated water buffaloes in China: Zooarchaeological investigations. Paper presented at the 3rd International Conference of the Society for East Asian Archaeology, 16-19 June, Daejeon, South Korea.

Lu, Hua-yu, Ko van Huissteden, Jie Zhou, Jef Vandenberghe, XiaO-dong Liu, and Zhi-Sheng AN

2000 Variability of East Asian winter monsoon in Quaternary climatic extremes in North China. Quaternary Research 54:321-327.

Lu, Tracey L.-D.

1998 Some botanical characteristics of green foxtail (Setaria viridis) and harvesting experiments on the grass. Antiquity 72(278):902-907.

1999 The Transition from Foraging to Farming and the Origin of Agriculture in China. BAR International Series No. 774. Oxford, UK: Hadrian Books.

2001 Les outlis de récolte de céréales néolithiques de la vallée du fleuve jaune (The Neolithic harvesting tools found in the Yellow River Valley). Annales de la Fondation Fyssen $16: 104-113$.

2002 A green foxtail (Setaria viridis) cultivation experiment in the middle Yellow River Valley and some related issues. Asian Perspectives 41(1):1-14.

2003 The palaeoenvironment and resources at Zengpiyan, in Zengpiyan: A Prehistoric Cave in South China (in Chinese): 251-269, ed. Institute of Archaeology, CASS et al. Beijing: Cultural Relics Publishing House.

2005 Dongya diqu gengxinshi moqi dao quanxinshi chuqi de wenhua fazhan (Cultural developments in East Asia from the terminal Pleistocene to the early Holocene) Dongya Guwu (East Asian Antiquities) $1: 1-18$.

MacNeish, Richard S., Geoffrey Cunnar, Zhijun Zhao, and Jane Libby

1998 Second Annual Report of the Sino-American Jiangxi (PRC) Origin of Rice Project SAJOR. Andover, MA.

Murdock, George P.

1967 The Ethnographic Atlas: A summary. Ethnology 6(2):109-236.

Nakayama, H., H. Namai, and K. Okuno

1999 Geographical variation of the alleles at the two prolamin loci, Pro. 1 and Pro. 2, in foxtail millet, Setaria italica (L.) P. Beauv. Genes and Genetic Systems 74(6):293-297.

National Bureau of Antiquity Management

2004 Major Archaeological Discoveries in China in 2003. Beijing: Cultural Relics Publishing House.

OKa, Hiko-IChi, and Hiroko Morishima

1970 The dynamics of plant domestication: Cultivation experiments with Oryza perennis and its hybrid with O. sativa. Evolution $25: 356-364$.

Pei, AN-PING

1995 Pengtoushan wenhua chulun (A preliminary discussion on the Pengtoushan culture). Paper presented at the Conference on the Prehistoric Culture in the Middle Yangzi River Valley, August.

2001 Notes on new advancements and revelations in the agricultural archaeology of early rice domestication in the Dongting Lake region. Antiquity 72:878-885.

Price, Douglas T., And Anne B. Gebauer

1995 New perspectives on the transition to agriculture, in Last Hunters, First Farmers: New Perspectives on the Prehistoric Transition to Agriculture: 1-19, ed. D. T. Price and A. B. Gebauer. Santa Fe, NM: School of American Research Press.

Price, Douglas T., and Anne B. Gebauer, eds.

1995 Last Hunters, First Farmers: New Perspectives on the Prehistoric Transition to Agriculture. Santa Fe, NM: School of American Research Press. 
Ren, Guoyu, and Hans-Juergen Beug

2002 Mapping Holocene pollen data and vegetation of China. Quaternary Science Reviews $21: 1395-1422$.

Rieseberg, Loren H., Alex Widmer, A. Michele Arntz, and John M. Burke

2002 Directional selection is the primary cause of phenotypic diversification. PNAS 99(19): $12,242-12,245$.

ShI, JiN-MING, Y. H. Song, AND Y. M. YAN

2002 Jixian Shizitan jiushiqi yizhiqun kaogu qude xinjinzhan (New progress on the Shizitan Palaeolithic sites in Ji County). Zhongguo Wenwubao (Chinese Antiquity News), 12 April, front page.

SMITH, BRUCE D.

1995 The Emergence of Agriculture. New York: Scientific American Library.

Stuiver, M., AND P. J. Reimer

2004 Radiocarbon calibration program, CALIB rev. 4.4.2. http://depts.washington.edu/qil/ calib.

Sun, C. Q., X. K. Wang, Z. C. Li, A. Yoshimura, and N. Iwata

2001 Comparison of the genetic diversity of common wild rice (Oryza rufipogon Griff) and cultivated rice (O. sativa L.) using RFLP markers. Theoretical and Applied Genetics 102:157162.

Sun, C. Q., X. K. Wang, A. Yoshimura, and K. DoI

2002 Genetic differentiation for nuclear, mitochondrial and chloroplast genomes in common wild rice (Oryza rufipogon Griff) and cultivated rice (O. sativa L.). Theoretical and Applied Genetics, online publication.

Sun, GUI-ZHI

1990 Hunan yeshengdao de shengjing jiqi tezheng, texing yanjiu (The characteristics and habitats of wild rice in Hunan), in Yeshengdao Ziyuan Lunwenji (Collected Papers on Wild Rice): 31-34, ed. Wu Mia-shen. Beijing: Chinese Science and Technologies Press.

TAKASHI, TSUTSUmi

2000 Adaptive strategies in the late glacial epoch and the origin of pottery, in The Origin of Rice Agriculture, Pottery and Cities: 65-80, ed. Yan Wenming and Yasuda Yoshinori. Beijing: Cultural Relics Publishing House.

TAO, LI-HUI

1994 Lun nongye qiyuan de dili huanjing (The natural environment of the origins of agriculture). Nongye Kaogu (Agricultural Archaeology) 1:36-40.

Tsang, Cheng-HWa

2005 Recent discoveries at the Tapenkeng culture sites in Taiwan: Implications for the problem of Austronesian origins, in The Peopling of East Asia: Putting Together Archaeology, Linguistics and Genetics: 63-73, ed. Laurent Sagart, Roger Blench, and Alicia Sanchez-Mazas. London and New York: RoutledgeCurzon.

Wang, JiAn, Xiang-QIAN Wang, and Zhe-Ying Chen

1978 Xiachuan wenhua (Xiachuan culture). Kaogu Xuebao (Archaeologica Sinica) 3:259-288.

WANG, XIANG-Kun, Chang-QIng Sun, AND Ju-Zhong Zhang

1998 Zhongguo zaipeidao qiyuan yanjiu de xianzhuang yu zhanwang (Current studies and future development on the origin of rice cultivation in China). Nongye Kaogu (Agricultural Archaeology) 1:11-20.

WANG, YOU-PING

1997 Gengxinshi Huanjing yu Zhongguo Nanfang Jiushiqi Wenhua Fazhan (The Pleistocene Environment and Cultural Development in South China). Beijing: Peking University Press.

Watson, Patty J.

1995 Explaining the transition to agriculture, in Last Hunters, First Farmers: New Perspectives on the Prehistoric Transition to Agriculture: 21-37, ed. D. T. Price and A. B. Gebauer. Santa Fe, NM: School of American Research Press.

XIA, NAI, ED.

1985 Encyclopedia of Chinese Archaeology. Beijing: Encyclopedia of China Press. 
Xiong L. Z., K. D. Liu, and X. K. Dai, C. G. Xu, and Qifa Zhang

1999 Identification of genetic factors controlling domestication-related traits of rice using an $\mathrm{F}_{2}$ population of a cross between Oryza sativa and O. rufipogon. Theoretical Applied Genetics 98:243-251.

YAN, WEN-MING

1992 The origins of agriculture and animal husbandry in China, in Pacific Northeast Asia in Prehistory: 113-123, ed. C. M. Aikens and S. N. Rhee. Washington: Washington University Press.

Yi, Sangheon, Yishiki Saito, Hideaki Oshima, Yong-Qing Zhou, and He-long Wei

2003 Holocene environmental history inferred from pollen assemblages in the Huanghe (Yellow River) delta, China: Climatic changes and human impact. Quaternary Science Reviews 22(5-7): 609-628.

You, XIU-LING

1987 Zhongguo gushu zhong jizai de yeshengdao tantao (Records of wild rice in Chinese historic documents). Gujin Nongye (Agriculture in the Past and Present) 1:1-6.

YUAN, JIA-RONG

2000 Hunan daoxian Yuchanyan 1 wannian yiqian de daogu he taoqi (Rice and pottery dated to 10,000 B.P. in Yuchanyan, Hunan), in Daozuo, Taoqi he Doushi de Qiyuan (The Origins of Rice Agriculture, Pottery and Cities): 31-42, ed. Yan Wenming and Y. Yoshinori. Beijing: Cultural Relics Publishing House.

YUAN, JING

2001 Zhongguo xinshiqi shidai jiaxu qiyuan de wenti (The origin of domesticated animals in Neolithic China). Wenwu (Relics) 5:51-58.

ZHANG, CHI

2000 Jiangxi Wannian zaoqi taoqi he daoshu zhiguishi yicun (Early pottery and rice phytolith found in Wannian, Jiangxi Province), in Daozuo, Taoqi he Doushi de Qiyuan (The Origins of Rice Agriculture, Pottery and Cities): 43-49, ed. Yan Wenming and Y. Yoshinori. Beijing: Cultural Relics Publishing House.

Zhang, Sen-shui, Xin-min Xu, Zhi-gang Luo, En-lin Wang, Bin Liu, Hong-liang Qiu, and YI-JIAN LIANG

2002 Gaixie Zhejiang wu jiushiqi wenhua yiwu didian de lish (It is the first time that Palaeolithic remains have been discovered in Zhejiang). Zhongguo Wenwubao (Chinese Antiquities News), 11 December, front page.

ZhaO, ChaO-HONG, Jin-Cheng Yu, and TAO Wang

2003 Beijing Donghulin xinshiqi shidai zaoqi yizhi huo zhongyao faxian (Important discoveries made at Neolithic Donghulin, Beijing). Zhongguo Wenwubao (Chinese Antiquity News), 9 May, front page.

ZHAO, ZHI-JUN

1998 The middle Yangtze in China is one place where rice was domesticated: Phytolith evidence from Diaotunghuan Cave, Northern Jiangxi. Antiquity 278:885-897.

Zhao, Zhi-jun, Deborah M. Pearsall, R. A. Benfer Jr., and Dolores R. Piperno

1998 Distinguishing rice (Oryza sativa poaceae) from wild Oryza species through phytolith analysis, II: Finalized method. Economic Botany 52(2):134-145.

ZHOU, BeN-XIONG

1984 Zhongguo xinshiqi shidai de jiaxu (Domesticated animals in Neolithic China), in Xinzhongguo de Kaogu Faxian he Yanjiu (Archaeological Discoveries and Research in New China): 194-198, ed. Institute of Archaeology, CASS. Beijing: Cultural Relics Publishing House.

ZHUSHCHIKHOVSKAYA, IRINA

1997 On early pottery-making in the Russian Far East. Asian Perspectives 36(2): 160-174.

\section{ABSTRACT}

This paper examines the progress and remaining problems on the occurrence of cereal cultivation in China, which led to agriculture, and discusses some related theoretical issues. Based on currently available data, it is argued that the occurrence of 
cereal cultivation in China was associated with and related to the climatic and environmental changes after the last glacial epoch, the occurrence of new technology, including the manufacturing of pottery, and the adoption of a broad-spectrum subsistence strategy, whereas sedentism does not seem to be a prerequisite for this cultural change. The transition from hunting-gathering to agriculture in China seems to have been a gradual process, and foraging remained a subsistence strategy of the early farmers. The occurrence of cereal cultivation in China differed from that in other core areas, demonstrating the diversity of human cultures and contributing to our understanding of the origin and development of agriculture in the world. KEYWORDS: foraging to farming, cereal cultivation, prehistory, China. 